\title{
Impact of microRNA-29b on natural killer cells in T-cell acute lymphoblastic leukemia
}

\author{
FENGYAN JIN, ZHONGHUA DU, YANG TANG, LIXIA WANG and YANPING YANG \\ Department of Hematology, First Bethune Hospital of Jilin University, Changchun, Jilin 130021, P.R. China
}

Received April 1, 2018; Accepted June 11, 2019

DOI: $10.3892 / \mathrm{ol} .2019 .10559$

\begin{abstract}
Natural killer (NK)-based immunotherapeutic strategies are showing promise in the clinic, particularly against acute myeloid leukemia (AML). Similar treatments for T-cell acute lymphoblastic leukemia (T-ALL) have been less successful, which is due to the higher resistance of T-ALL blasts to the cytotoxic function of NK cells. Herein, microRNA-29b (miR-29b) upregulation was identified in NK cells in both neurogenic locus notch homolog protein 1 (Notch1)-T-ALL mice and patients with T-ALL. Furthermore, miR-29b expression levels were downregulated in T-ALL blast cells. In addition, there was a selective downregulation of an immature subset of NK cells, as well as a reduction in interferon $\gamma($ IFN $\gamma)$ production and natural killer receptor group 2, member D (NKG2D) expression level by NK cells in Notch1-T-ALL mice and patients with T-ALL. Furthermore, when miR-29b knock-out NK cells were adoptively transfused into Notch1-T-ALL mice, partial restoration of IFN $\gamma$ production and NKG2D expression was observed in NK cells, accompanied by retarded ALL progression and improved survival time. These results implied that T-ALL blast immune evasion occurred via miR-29b-mediated dysregulation in NK cells in the T-ALL microenvironment.
\end{abstract}

\section{Introduction}

T-cell acute lymphoblastic leukemia (T-ALL), a highly aggressive hematological malignancy, carries an increased risk of treatment failure and relapse compared with B-cell acute lymphoblastic leukemia (B-ALL) (1). The majority of studies investigating natural killer $(\mathrm{NK})$ cell recognition in ALL have focused on B-ALL $(2,3)$, while a limited number of studies have investigated the role of NK cells in T-ALL. Thus,

Correspondence to: Dr Yanping Yang, Department of Hematology, First Bethune Hospital of Jilin University, 71 Xinmin Street, Changchun, Jilin 130021, P.R. China

E-mail: yangyanping_1978@163.com

Key words: T-cell acute lymphoblastic leukemia, microRNA-29b, natural killer cells, interferon $\gamma$, natural killer receptor group 2, member D there is a requirement for studies surrounding the mechanism of immune surveillance escape in T-ALL, with the aim to improve the success of therapeutic strategies.

NK cells are important innate immune surveyors that are critical for the removal of leukemia blasts. It has been reported that following bone marrow transplantation, NK cells are able to effectively destroy leukemia blasts in patients with acute myeloid leukemia (AML) (4). However, the NK response to treatments for T-ALL is limited $(5,6)$. Factors that affect immune surveillance by NK cells are characterized as immune escape strategies used by leukemia blasts, including the downregulation of NK cell cytotoxicity and activation receptors, upregulation of inhibitory NK cell receptors and secretion of soluble NK-inhibitory factors $(7,8)$. In ALL, it has been reported that T-ALL blasts downregulate cell-surface ligands that activate NK cell receptors, facilitating immune surveillance escape $(5,6)$. NK cells exist in distinct functional subsets that are characterized by their surface antigen profiles. Further investigation of the NK cell maturation phenotype in T-ALL is required, as to date, the effects of maturation arrest in T-ALL have not been evaluated.

The murine NK cell maturation process consists of four stages: CD27-CD11b $\rightarrow \mathrm{CD}^{-} 7^{+} \mathrm{CD}^{-} 11 \mathrm{~b}^{-} \rightarrow \mathrm{CD}^{-} 7^{+} \mathrm{CD}^{-} 1 \mathrm{~b}^{+} \rightarrow$ $\mathrm{CD}^{2} 7^{-} \mathrm{CD} 11 \mathrm{~b}^{+}(9)$; Murine $\mathrm{CD} 11 \mathrm{~b}^{+} \mathrm{mNK}$ subsets can be further categorized into $\mathrm{CD} 27^{+}$and $\mathrm{CD} 27^{-}$populations. $\mathrm{CD} 11 \mathrm{~b}^{+} \mathrm{CD} 27^{+}$ $\mathrm{NK}$ cells produce a greater range of cytokines and exhibit increased cytotoxicity compared with their CD27- counterparts (10). Human mature NK subsets are characterized as CD56 $6^{\text {bright }} \mathrm{CD} 16^{\mathrm{dim}}$ or $\mathrm{CD} 56^{\mathrm{dim}} \mathrm{CD} 16^{\text {bright }}(11) . \mathrm{CD}^{\mathrm{b}} 6^{\text {bright }} \mathrm{CD} 16^{\mathrm{dim}}$ $\mathrm{NK}$ cells are the precursors to $\mathrm{CD} 56^{\mathrm{dim}} \mathrm{CD} 16^{\text {bright }} \mathrm{NK}$ cells, which predominantly reside in secondary lymphoid tissue, produce a wider range of cytokines, including interferon $\gamma$ (IFN $\gamma$ ), tumor necrosis factor- $\beta$, interleukin (IL)-10, IL-13 and granulocyte-macrophage colony-stimulating factor, but are less cytotoxic. By contrast, CD56 ${ }^{\text {dim }} \mathrm{CD} 16^{\text {bright }} \mathrm{NK}$ cells, enriched in the peripheral blood, produce fewer cytokines but are more cytotoxic. As a result, CD56 ${ }^{\text {bright }} \mathrm{CD} 16^{\text {dim }} \mathrm{NK}$ cells are the primary IFN $\gamma$-producing subset (12-14). The majority of NK-mediated anti-leukemia activity is the result of IFN $\gamma$ production, which is partially attributed to the upregulation of natural killer receptor group 2, member D (NKG2D) (15), and which in turn activates NK cells via the DAP10 and/or DAP12 signaling pathways (16).

MicroRNAs (miRs) serve an important role in regulating the development and functions of NK cells $(17,18)$. However, the 
importance of miRs in regulating NK cells in T-ALL has not been investigated. Due to $>50 \%$ of human T-ALL exhibiting activating neurogenic locus notch homolog protein 1 (Notch1) mutations (19), the present study demonstrated the effects of miR-29b on the dysregulation of NK cell phenotype and function in Notch1-T-ALL mice. The selective downregulation of $\mathrm{CD} 27^{+} \mathrm{CD} 11 \mathrm{~b}^{+} \mathrm{NK}$ cell subset was revealed, in addition to a reduction in IFN- $\gamma$ secretion and NKG2D expression on NK cells. Furthermore, the upregulation of miR-29b expression level was observed, which may have regulatory effects on NK cell development.

\section{Materials and methods}

Animals. Wild type (WT) C57BL/6, C57BL/6 Rag2-/- and $\mathrm{C} 57 \mathrm{BL} / 6 \mathrm{miR} 29 \mathrm{ab} 1^{-/}$mice were bred in pathogen-free conditions at the animal center affiliated to the First Bethune Hospital (Changchun, China). Following experimentation, the animals were sacrificed by cervical dislocation; the thumb and index finger were placed on either side of the neck at the base of the skull. With the other hand, the base of the tail was quickly pulled, causing separation of the cervical vertebrae from the skull. Death was verified by the lack of continuous spontaneous breathing or blinking reflex.

Notch1-T-ALL mice and NK cell infusion. NK cells were prepared as previously described (20). Notch1-T-ALL blasts were prepared and injected into mice as previously described (21). The Notch1-T-ALL blasts used in the present study contained $>95 \%$ leukemia (GFP+) cells. C57BL/6 mice or C57BL/6 Rag $2^{-/-}$mice received $2 \times 10^{5}$ Notch1-T-ALL blasts. In the NK cell transfusion experiment, $2 \times 10^{7} \mathrm{WT}$ NK cells or miR-29b knock-out (KO) NK cells were injected into C57BL/6 Rag2 $2^{-/-}$mice.

Patients. Fresh peripheral blood samples with $\mathrm{CD}^{+} \mathrm{T}-\mathrm{ALL}$ blasts were obtained from 8 newly diagnosed T-ALL patients (5 males and 3 females), aged 20-56 years old, in the Hematology department of the First Bethune Hospital between March 2017 and September 2017. Fresh peripheral blood of the age-and sex-matched healthy control group was obtained from volunteers at the hospital in the same time period.

Cell isolation. Fresh peripheral blood was layered onto Ficoll (cat. no. 171440-02; GE Healthcare) and centrifuged at $400 \mathrm{x} \mathrm{g}$ for $10 \mathrm{~min}$ at room temperature. NK cells, $\mathrm{CD}^{+} \mathrm{T}$ cells and $\mathrm{CD}^{+} \mathrm{T}$-ALL blasts were collected from the single-cell suspension and sorted for immunophenotypic analysis or quantitative reverse transcription-quantitative polymerase chain reaction (RT-qPCR) analysis as described below. The NK cell subset was enriched using the human NK cell isolation kit (cat. no. 17955; STEMCELL Technologies), and $\mathrm{CD}^{+} \mathrm{T}$ cells were enriched using the human $\mathrm{CD}^{+} \mathrm{T}$-cell isolation kit (cat. no. 17951; STEMCELL Technologies) according to the manufacturer's recommendations. Human T-ALL blasts were enriched by positive selection from the CD3 ${ }^{-}$population, using anti-CD7 (cat. no. 239299; Abcam), anti-CD45 (cat. no. 40763; Abcam) and anti-CD34 (cat. no. 157304; Abcam) antibodies. The procedure was carried out according to the manufacturer's recommendations of the fluorescence activated cell sorter (FACS) Aria ${ }^{\mathrm{TM}}$ III (BD Biosciences). CD56 ${ }^{\text {bright }}$ CD16 ${ }^{\mathrm{dim}}$ or $\mathrm{CD} 56^{\mathrm{dim}} \mathrm{CD} 16^{\text {bright }} \mathrm{NK}$ cell subsets were also isolated according to these recommendations. Mouse mononuclear cells from the bone marrow, spleen and peripheral blood were collected according to a previous study (21). NK1.1 $1^{+} \mathrm{CD} 3$ cells were enriched using the murine NK cell isolation kit (cat. no. 17855; Stem Cell Technologies) and CD3 ${ }^{+} \mathrm{T}$ cells were enriched with the mouse T cell isolation kit (cat. no. 19851; Stem Cell Technologies) as per the manufacturer's protocols. GFP+ murine Notch1-T-ALL blasts were isolated using the FACS Aria ${ }^{\mathrm{TM}}$ III sorter (BD Biosciences). All sorted cells were identified to be $>99 \%$ pure using the FACS Canto ${ }^{\mathrm{TM}}$ II flow cytometer (BD Biosciences).

Antibodies and flow cytometry. Mononuclear cells from humans or mice were prepared as above. Antibodies purchased from BD Biosciences included: mouse anti-mouse NK1.1-APC (cat. no. 550627), rat anti-mouse CD3-PE (cat. no. 565643), rat anti-mouse CD11b-V450 (cat. no. 560455), mouse anti-human CD56-Alexa Fluor ${ }^{\circledR}$ (cat. no. 557919), mouse anti-human CD3-PerCP (cat. no. 347,344), mouse anti-human CD16-PE-cy7-A (cat. no. 557744), mouse anti-human CD34-PE-CF594 (cat. no. 550761), mouse anti-human-CD45-BV650 (cat. no. 563717) and mouse anti-human-CD7-APC (cat.no.561604).Anti-mouse/rat/human CD27-PECy7 (cat. no. 124215) was purchased from BioLegend, Inc.; rat anti-mouse IFN $\gamma$-APC (cat. no. 554413) and isotype control mouse IgG2a (cat. no. 551414) were obtained from BD Pharmingen (BD Biosciences). Notch1-T-ALL cells were identified as $\mathrm{GFP}^{+}$.

Analysis of intracellular IFN $\gamma$ expression. Intracellular production of IFN $\gamma$ was analyzed using rat anti-mouse IFN $\gamma$-APC, as previously reported (16). Briefly, freshly isolated splenocytes from Notch1-T-ALL mice and control C57BL/6 mice were labeled with anti-NK1.1 and anti-CD3 antibodies for $6 \mathrm{~h}$; followed by fixation, permeabilization, and labeling with anti-IFN $\gamma$ antibodies. Cells were subsequently evaluated using the FACS Canto ${ }^{\mathrm{TM}}$ II flow cytometer (BD Biosciences).

Cell lines and cytotoxicity assays. The EL4 cell line (C57BL/6 origin) was obtained from the laboratory of the Translational Medicine Institution in Jilin University, and was thawed from a frozen stock. EL4 cells were cultured in RPMI 1640 (cat. no. 11875085; Thermo Fisher Scientific, Inc.) supplemented with $100 \mathrm{U} / \mathrm{ml}$ penicillin (cat. no. 15140163; Thermo Fisher Scientific, Inc.), $10 \%$ fetal bovine serum (cat. no. 10437028; Thermo Fisher Scientific, Inc.), $100 \mu \mathrm{g} / \mathrm{ml}$ streptomycin (cat. no. 15070063; Thermo Fisher Scientific, Inc.) and $50 \mu \mathrm{mol} / 1$ 2-mercaptoethanol (cat. no. 21985023; Thermo Fisher Scientific, Inc.), at $37^{\circ} \mathrm{C}$ with $5 \% \mathrm{CO}_{2}$. EL4 and Notch1-T-ALL blasts were cultured with NK cells in standard 4-h chromium release assay as reported previously (22).

$R T-q P C R$. Total RNA was isolated from NK cells, Notch1-T-ALL blasts and T-ALL blasts using the RNAqueous ${ }^{\mathrm{TM}}$ Total RNA Isolation kit (cat. no. AM1912; Invitrogen; Thermo Fisher Scientific, Inc.,), followed by reverse transcription using the High-Capacity cDNA Reverse Transcription kit (cat. no. 4368814; Applied Biosystems; Thermo Fisher Scientific, Inc.), according 
Table I. Primers for reverse transcription-quantitative PCR.

Name

Forward primer (5'-3')

Reverse primer $\left(5^{\prime}-3^{\prime}\right)$

$\begin{array}{ll}\text { Human NKG2D } & \text { TTGATGGGGTGGATTCGTGG } \\ \text { Human IFN } \gamma, & \text { AGCTCTGCATCGTTTTGGGT } \\ \text { Mouse NKG2D, } & \text { AGCCAGCAAAGTGGGATACT } \\ \text { Mouse IFN } \gamma, & \text { ACGGCACAGTCATTGAAAGC } \\ \text { Human GAPDH } & \text { GAAGGTGAAGGTCGGAGT } \\ \text { Mouse GAPDH } & \text { GGCAAATTCAACGGCACAGT }\end{array}$

TCTCGGTTGGCAGTGTTACC CGCTTCCCTGTTTTAGCTGC CTGGGACTTCCTTGTTGCAC CGAATCAGCAGCGACTCCTT CATGGGTGGAATCATATTGGAA TAGGGCCTCTCTTGCTCAGT

NKG2D, natural killer receptor group 2, member D; IFN, interferon.

to the manufacturer's protocols. qPCR was performed using the SYBR ${ }^{\circledR}$ Green master mix (cat. no. 4334973; Applied Biosystems; Thermo Fisher Scientific, Inc.) on a QuantStudio ${ }^{\mathrm{TM}}$ 6 Flex Real-Time PCR system (Applied Biosystems; Thermo Fisher Scientific, Inc.). The primers for murine and human IFN $\gamma$, NKG2D and GAPDH are listed in Table I. miR-29b expression was detected using the murine and human microRNA-29b TaqMan $^{\mathrm{TM}}$ microRNA assay (cat. no. 4427975 (000413); Thermo Fisher Scientific, Inc.), the murine U6 control TaqMan ${ }^{\mathrm{TM}}$ microRNA assay (cat. no. 4427975 (001973); Thermo Fisher Scientific, Inc.), and the human RNU6B control TaqMan ${ }^{\mathrm{TM}}$ microRNA assay (cat. no. 4427975 (001093); Thermo Fisher Scientific, Inc.). The thermocycling conditions were as follows: $95^{\circ} \mathrm{C}$ for $2 \mathrm{~min} ; 40$ cycles of $95^{\circ} \mathrm{C}$ for $15 \mathrm{sec}, 60^{\circ} \mathrm{C}$ for $15 \mathrm{sec}$ and $68^{\circ} \mathrm{C}$ for $30 \mathrm{sec}$. Gene expression was normalized to an internal control and the relative mRNA expression level of each gene was determined using the as $2^{-\Delta \Delta \mathrm{Cq}}$ method (17).

Statistical analysis. The unpaired Student's t-test was used to statically analyze the differences between two independent groups. Multiple comparisons between groups were performed using one-way ANOVA followed by the S-N-K method. The flow cytometry results were analyzed using FlowJo 10.0.7 software (FlowJo LLC), and the RT-qPCR data was analyzed using SPSS 12.0 (SPSS, Inc.). Survival rates were analyzed using Kaplan-Meier analysis and the log-rank test of Prism 5 (GraphPad Software, Inc.). Data are presented as the mean \pm standard deviation. $\mathrm{P}<0.05$ was considered to indicate a statistically significant difference.

\section{Results}

Alterations to miR-29b expression level in NK cells and leukemia blasts in T-ALL. An increase in the expression levels of miR-29b in NK cells has previously been associated with an aggressive disease phenotype $(21,23)$. Specifically, a recent study reported that increased levels of miR-29b expression influenced the differentiation and function of NK cells in AML (17). To determine whether miR-29b dysregulation also occurred in T-ALL, the expression levels of miR-29b were determined in mouse NK cells 21 days after Notch1-T-ALL blast administration. There was a significant increase in the miR-29b expression level of NK cells from the spleen of Notch1-T-ALL mice, compared with that of the control mice $(9.47 \pm 3.83$ vs. $1.50 \pm 1.03 ; \mathrm{P}=0.0005$; Fig. $1 \mathrm{~A})$.
Human mature NK cells were characterized as $\mathrm{CD} 6^{\text {bright }} \mathrm{CD} 16^{\mathrm{dim}}$ or CD56 ${ }^{\text {dim }} \mathrm{CD} 16^{\text {bright }}$. The $\mathrm{CD} 56^{\mathrm{dim}} \mathrm{CD} 16^{\text {bright }}$ $\mathrm{NK}$ subset is more common in the peripheral blood, and exhibits higher cytotoxicity, but a lower level of cytokine production compared with the CD56 ${ }^{\text {high }} \mathrm{CD} 16^{\mathrm{dim}} \mathrm{NK}$ subset (12). It was determined that a similar increased level of miR-29b expression level occurred in NK cells from the peripheral blood of patients with T-ALL; the miR-29b expression in the $\mathrm{CD} 6^{\text {bright }} \mathrm{CD} 16^{\mathrm{dim}} \mathrm{NK}$ cell subset of untreated patients with newly diagnosed T-ALL was compared with that of the healthy age-matched control group. The results revealed a significantly increased level of miR-29b expression in the CD56 ${ }^{\text {bright }}$ CD16 ${ }^{\text {dim }} \mathrm{NK}$ cell subset from T-ALL patients, compared with that of the healthy control group $(2.13 \pm 0.87 \mathrm{vs}$. $0.91 \pm 0.48$; $\mathrm{P}=0.0039$; Fig. 1B). These results suggested that NK cells express increased levels of miR-29b in both murine Notch1-T-ALL mice and T-ALL patients.

Previous studies have indicated the occurrence of miRNA exchange between cells in chronic leukemia $(24,25)$. In addition, increased miR-29b expression levels in NK cells are associated with decreased expression in AML blasts (17). The present study investigated whether a similar reduction in miR-29b expression level occurred in T-ALL blasts. 21 days after the administration of Notch1-T-ALL blasts into mice, the miR-29b expression level in splenic blasts had decreased, compared with that in the splenic WT CD3 ${ }^{+} \mathrm{T}$ cells of mice without blast transfer $(0.25 \pm 0.17$ vs. $1.04 \pm 0.11 ; \mathrm{P}=0.0026$; Fig. 1C). Furthermore, it was demonstrated that the miR-29b expression level decreased in Notch1-T-ALL blasts from the peripheral blood of patients with T-ALL, compared with that in $\mathrm{T}$ cells from the peripheral blood of healthy individuals $(0.48 \pm 0.18$ vs. $0.94 \pm 0.18 ; \mathrm{P}=0.0315$; Fig. 1D). These data indicated that miR-29b expression was dysregulated in both T-ALL mice and patients. Opposing trends in miR-29b expression levels were observed between NK cells and leukemic blasts in the T-ALL microenvironment.

NK cell subset alterations in Notch1-T-ALL mice and patients with $T$-ALL. A previous study demonstrated that the absolute number of $\mathrm{CD} 27^{+} \mathrm{CD} 11 \mathrm{~b}^{+} \mathrm{NK}$ cells increased in the peripheral blood, spleen and bone marrow of AML mice, which was associated with an increase in NK cell miR-29b expression level (17). Therefore, the present study investigated NK cell subsets in Notch1-T-ALL mice. A significant reduction in the $\mathrm{CD} 27^{+} \mathrm{CD} 11 \mathrm{~b}^{+}$subset in the spleens of Notch1-T-ALL mice was 
A

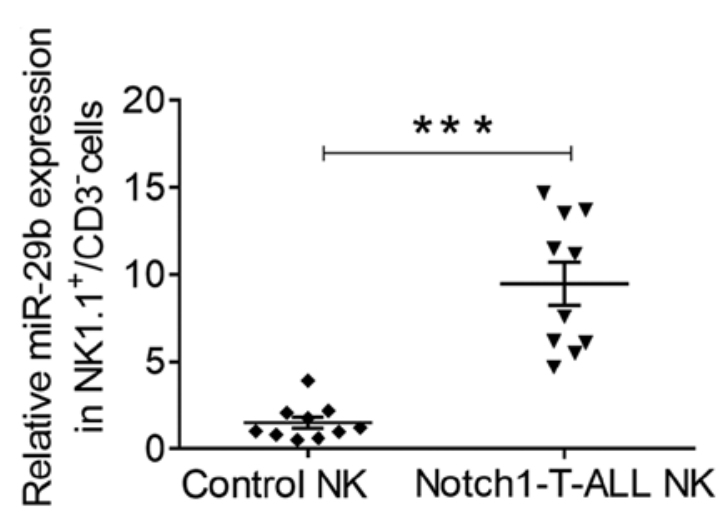

C

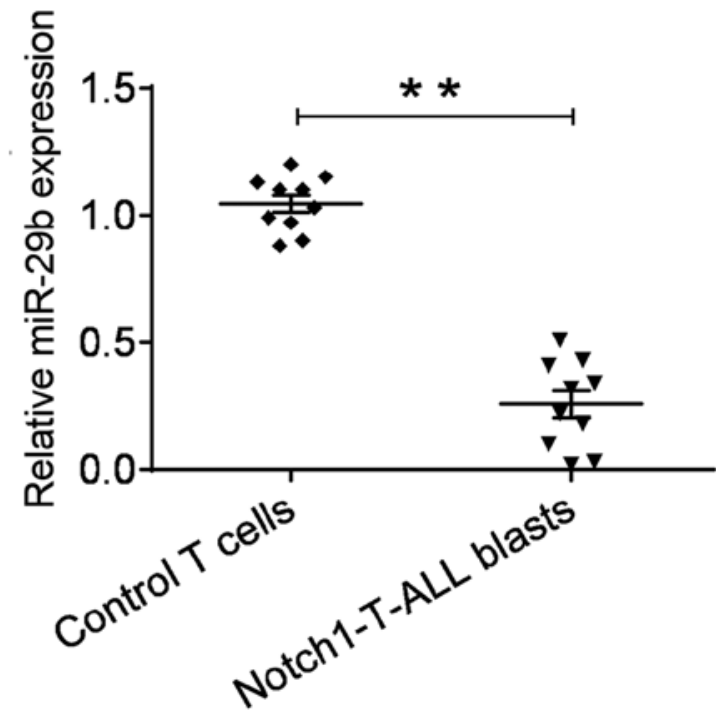

B
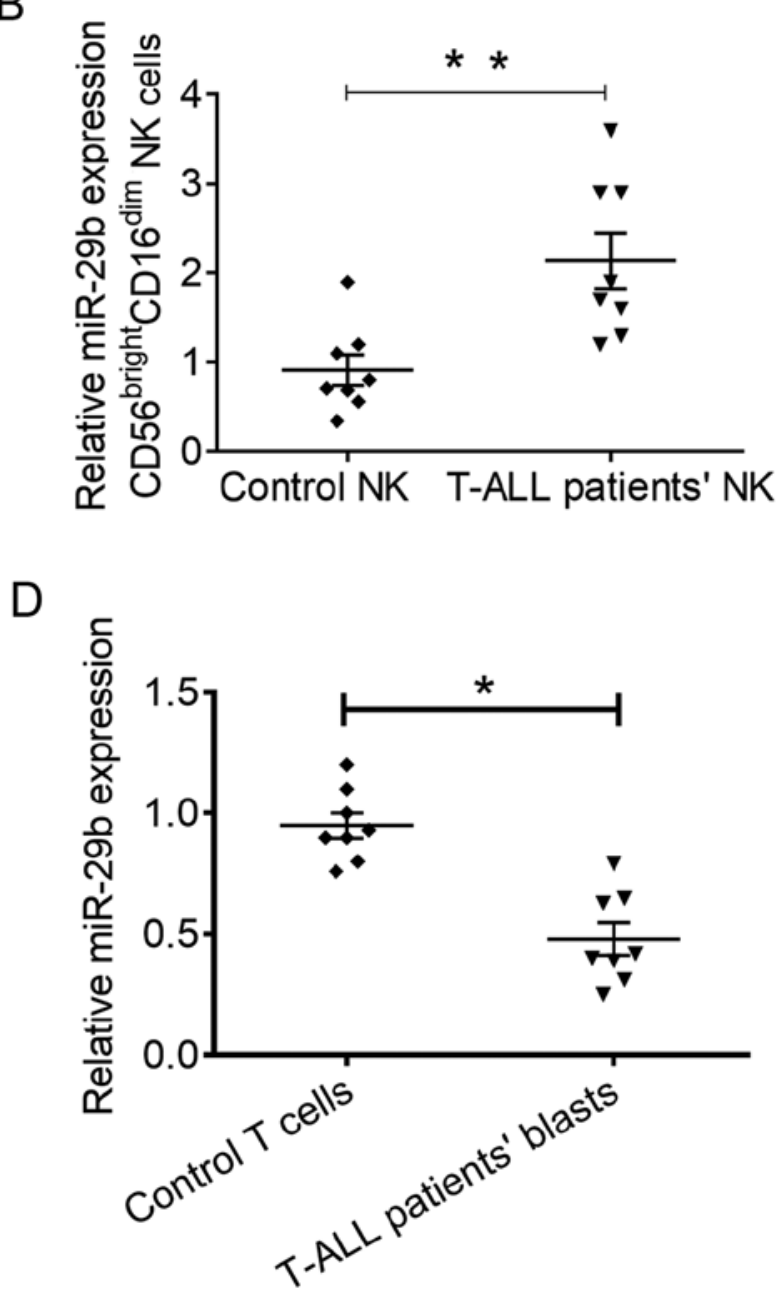

Figure 1. miR-29b expression levels in T-ALL NK cells and leukemia blasts. Relative miR-29b expression levels were determined using quantitative reverse transcript-quantitative PCR. The relative expression values presented as relative fold change on the y-axes were relative to the average value of the normal controls. (A) Relative expression levels of miR-29b in splenic NK1.1 ${ }^{+}$CD3-NK cells from control WT C57BL/6 mice or Notch1-T-ALL C57BL/6 mice. (B) Relative miR-29b expression levels in peripheral blood CD56 $6^{\text {bright }}$ CD16 ${ }^{\text {dim }}$ NK cells from newly diagnosed, untreated patients with T-ALL and healthy controls. (C) Relative miR-29b expression levels in splenic Notch1-T-ALL blasts from Notch1-T-ALL mice or in splenic T cells from control WT C57BL/6 mice. (D) Relative miR-29b expression levels in peripheral blood T-ALL blasts from patients with T-ALL or healthy controls. A and C: $\mathrm{n}=10$ mice per group; $\mathrm{B}$ and $\mathrm{D}$ : $\mathrm{n}=8$ healthy control group, $\mathrm{n}=8$ untreated T-ALL patients. The data are presented as the mean \pm standard deviation. ${ }^{*} \mathrm{P}<0.05,{ }^{* *} \mathrm{P}<0.01$ and ${ }^{* * *} \mathrm{P}<0.001$, as determined using the unpaired Student's t-test. T-ALL, T-cell acute lymphoblastic leukemia; NK, natural killer; miR, microRNA; WT, wild type; Notch1, neurogenic locus notch homolog protein 1.

observed compared with that in control WT C57BL/6 mice (37.94 $\pm 10.07 \%$ vs. $18.34 \pm 7.65 \%$; $\mathrm{P}=0.0085$; Fig. $2 \mathrm{~A})$. There was no significant change in the numbers of the most mature $\left(\mathrm{CD} 27^{-} \mathrm{CD}^{\left.-11 b^{+}\right)}\right.$or the most immature $\left(\mathrm{CD} 27^{-} \mathrm{CD} 11 \mathrm{~b}^{-}\right) \mathrm{NK}$ cells $(44.46 \pm 8.09 \%$ vs. $38.52 \pm 11.23 \%, \mathrm{P}=0.2915 ; 2.06 \pm 1.55 \%$ vs. $3.96 \pm 2.90 \%, P=0.0593$, respectively; Fig. 2 A). However, the $\mathrm{CD} 27^{+} \mathrm{CD} 11 \mathrm{~b}-$ subset increased significantly in Notch1-T-ALL mice $(16.36 \pm 5.46 \%$ vs. $40.85 \pm 11.32 \%$; $\mathrm{P}=0.0024$; Fig. $2 \mathrm{~A})$.

Furthermore, the absolute number of the NK cell subsets in the spleen, peripheral blood and bone marrow of Notch1-T-ALL mice was evaluated and compared with control mice. The data revealed that the $\mathrm{CD} 27^{+} \mathrm{CD} 11 \mathrm{~b}^{+}$subset was significantly reduced in the spleen $\left(6.58 \pm 2.38 \times 10^{5} / 1\right.$ vs. $3.36 \pm 1.59 \times 10^{5} / 1 ; \mathrm{P}=0.0036$; Fig. 2B), peripheral blood $\left(0.90 \pm 0.47 \times 10^{5} / 1\right.$ vs. $0.11 \pm 0.05 \times 10^{5} / 1$; $\mathrm{P}=0.0061$; Fig. $2 \mathrm{C})$ and bone marrow $\left(2.29 \pm 1.34 \times 10^{5} / 1 \mathrm{vs}\right.$. $0.23 \pm 0.14 \times 10^{5} / 1 ; \mathrm{P}=0.0089$; Fig. 2D). Also, CD $27^{+} \mathrm{CD} 11 \mathrm{~b}-\mathrm{NK}$ cells were increased in the spleen $\left(3.59 \pm 1.36 \times 10^{5} / 1 \mathrm{vs}\right.$. $9.30 \pm 2.68 \times 10^{5} / 1 ; \mathrm{P}=0.0029$; Fig. 2B) and peripheral blood $\left(0.38 \pm 0.24 \times 10^{5} / 1\right.$ vs. $1.12 \pm 0.28 \times 10^{5} / 1 ;=0.0022$; Fig. $\left.2 \mathrm{C}\right)$ of Notch1-T-ALL mice, compared with those of the control mice. However, this cell subset was decreased in the bone marrow of Notch1-T-ALL mice, compared with that in the control mice $\left(3.77 \pm 0.88 \times 10^{5} / 1\right.$ vs. $2.19 \pm 0.99 \times 10^{5} / 1 ; \mathrm{P}=0.0372$; Fig. $\left.2 \mathrm{D}\right)$. This may be due to the presence of T-ALL blasts in the bone marrow of Notch1-T-ALL mice, which may result in reduced hemocyte production compared with that of the control group. These data illustrated the developmental retardation of the $\mathrm{CD} 27^{+} \mathrm{CD} 11 \mathrm{~b}-\mathrm{NK}$ cell subset in Notch1-T-ALL mice.

In the peripheral blood, $90 \%$ of NK cells are characterized as CD56 ${ }^{\mathrm{dim}} \mathrm{CD} 16^{\text {bright }}$, and only $10 \%$ as $\mathrm{CD}^{\text {bright }} \mathrm{CD}^{\mathrm{b}} 6^{\mathrm{dim}}(11)$. NK cells were identified in the peripheral blood of eight T-ALL patients at diagnosis, and in age-matched healthy volunteers. The percentage of CD56 $6^{\text {bright }} \mathrm{CD} 16^{\mathrm{dim}} \mathrm{NK}$ cells in the total NK cell population was decreased in patients with T-ALL, compared with that in the control group $(5.69 \pm 2.53 \%$ vs. $9.54 \pm 2.26 \%$; $\mathrm{P}=0.0065$; Fig. 2E). In addition, a corresponding elevation in 
A

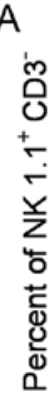

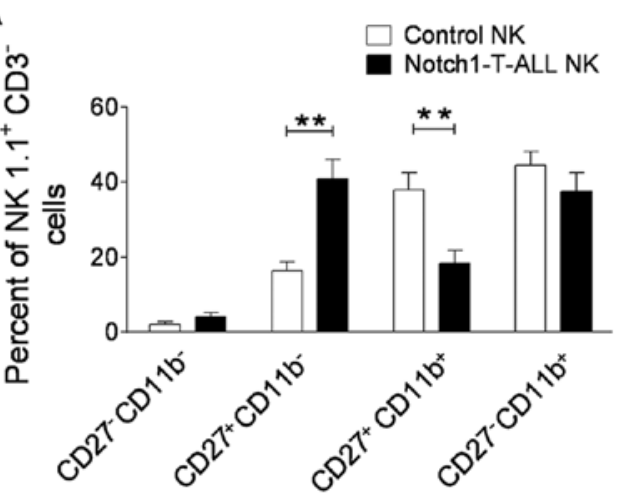

$\mathrm{B}$

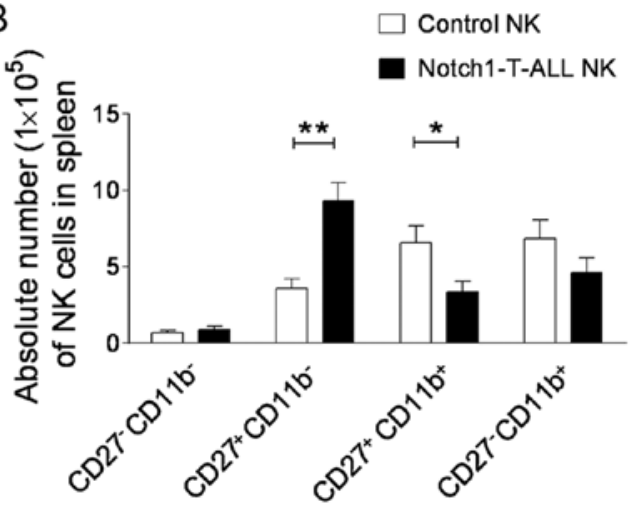

D

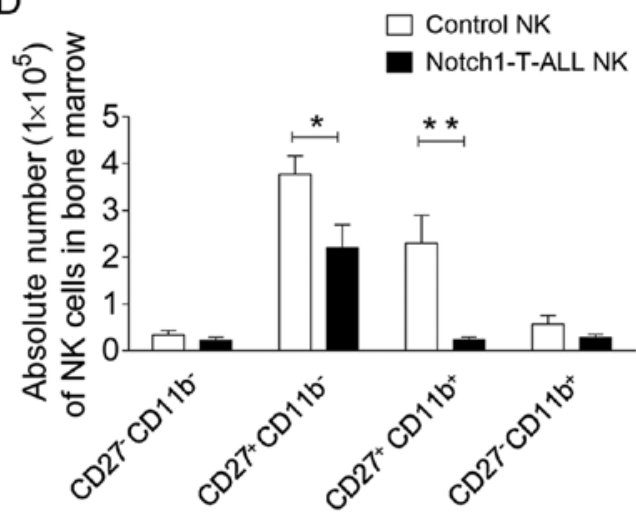

$\mathrm{F}$

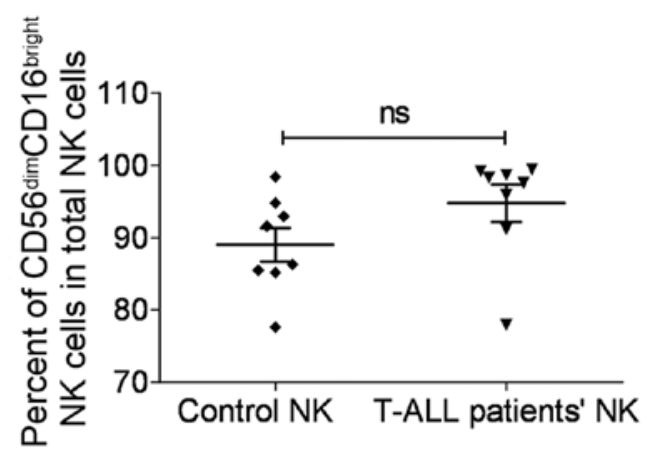

G

$\mathrm{E}$

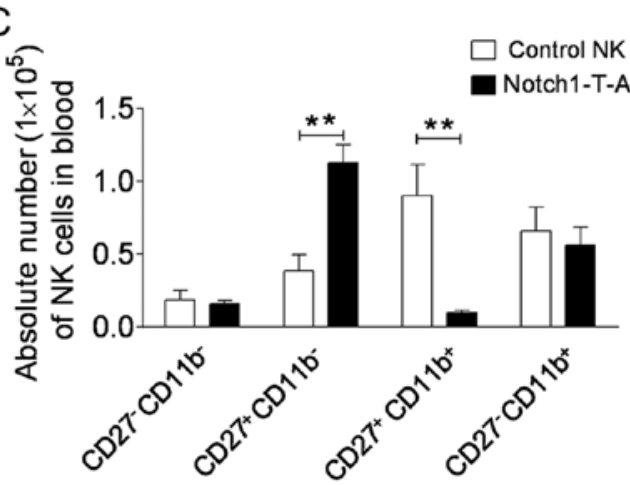

.
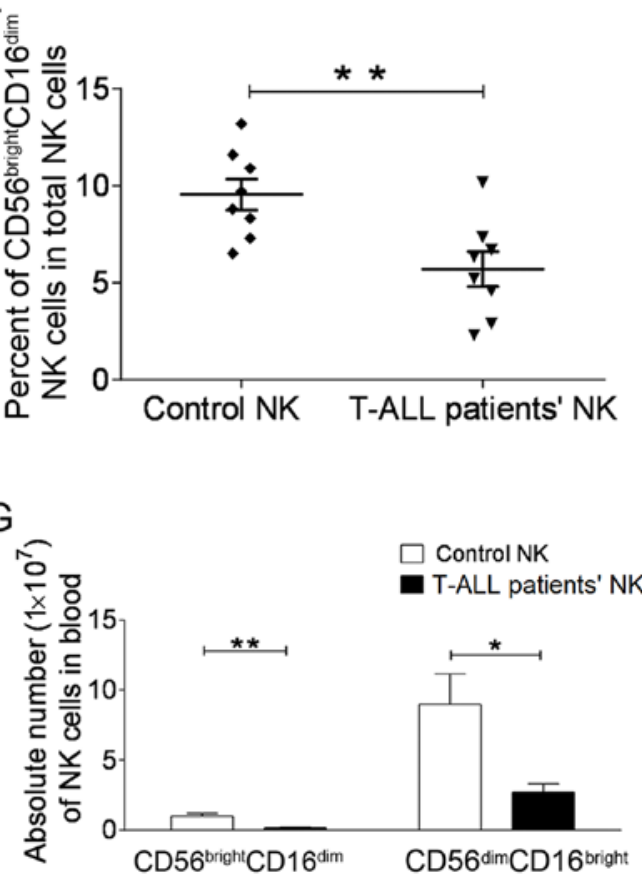

Figure 2. Mature NK cell populations are altered in both Notch1-T-ALL mice and patients with T-ALL. Freshly isolated splenocytes were obtained from Notch1-T-ALL mice or control WT C57BL/6 mice. (A) Percentage of CD27-CD11b ${ }^{-}$CD27 $7^{+}$CD11b ${ }^{-}$CD27 $7^{+}$CD11b ${ }^{+}$and CD27-CD11b ${ }^{+} \mathrm{NK}^{-}$cells in NK1.1 ${ }^{+}$ CD3 ${ }^{-} \mathrm{NK}$ cell populations. Absolute numbers of NK cell subsets from the (B) spleen, (C) peripheral blood and (D) bone marrow. Freshly isolated peripheral blood cells from newly diagnosed patients with T-ALL or healthy controls. (E) Percentage of CD56 $6^{\text {bright }} \mathrm{CD} 16^{\text {dim }}$ and $(\mathrm{F}) \mathrm{CD} 56^{\text {dim }} \mathrm{CD} 16^{\text {bright }} \mathrm{NK}$ cells in the total NK cell population. $(\mathrm{G})$ Absolute number of CD56 ${ }^{\text {bright }} C D 16^{\text {dim }}$ and CD56 ${ }^{\text {dim }}$ CD16 $6^{\text {bright }}$ NK cells. A-D: $n=10$ mice per group. E-G: $n=8$ healthy control group, and $\mathrm{n}=8$ untreated T-ALL patients. The data are presented as the mean \pm standard deviation; ${ }^{*} \mathrm{P}<0.05$ and ${ }^{* * *} \mathrm{P}<0.01$, as determined by one-way $\mathrm{ANOVA}$ or the unpaired Student's t-test. T-ALL, T-cell acute lymphoblastic leukemia; NK, natural killer; Notch1, neurogenic locus notch homolog protein 1; ns, not significant.

the percentage of CD56 ${ }^{\mathrm{dim}} \mathrm{CD} 16^{\text {bright }} \mathrm{NK}$ cells from T-ALL patients was detected, compared with that of the healthy controls ( $89.04 \pm 6.62 \%$ vs. $94.78 \pm 7.32 \%$; $\mathrm{P}=0.1228$; Fig. $2 \mathrm{~F})$. As predicted, the absolute number of $\mathrm{CD} 56^{\text {bright }} \mathrm{CD} 16^{\text {dim }} \mathrm{NK}$ cells was reduced in patients with T-ALL, compared with the healthy control group $\left(0.15 \pm 0.07 \times 10^{7} / 1\right.$ vs. $0.99 \pm 0.45 \times 10^{7} / 1 ; P=0.0034$; Fig. $\left.2 \mathrm{G}\right)$. Again, 
A

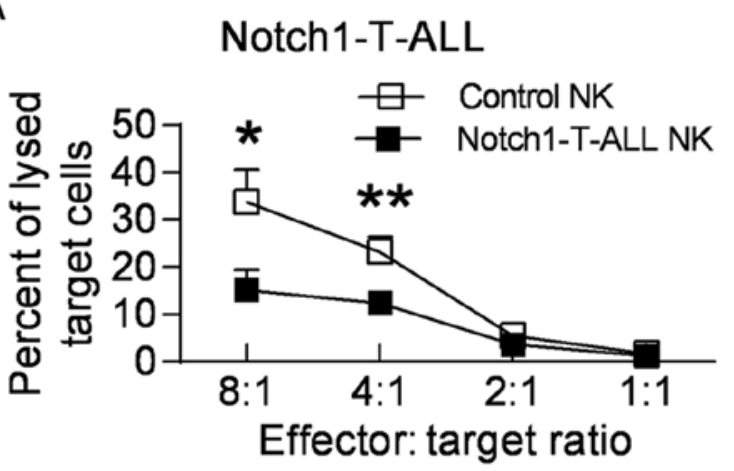

C

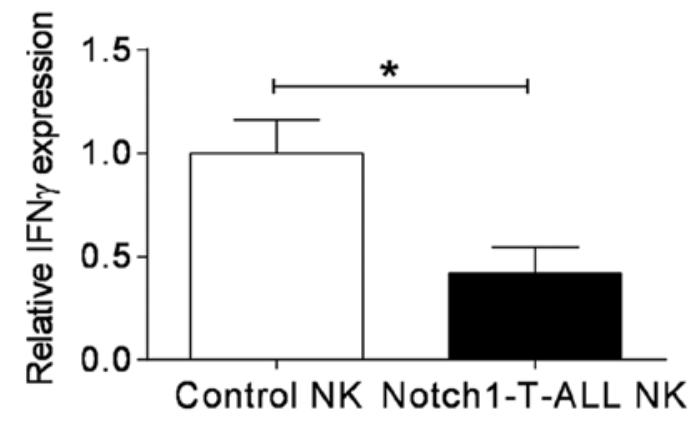

E

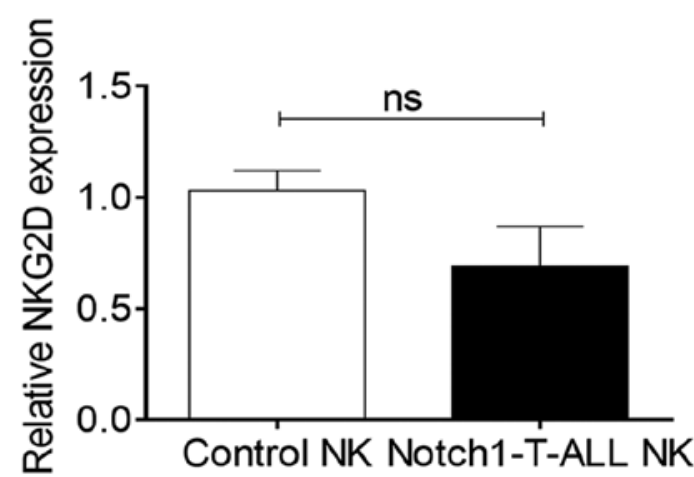

B
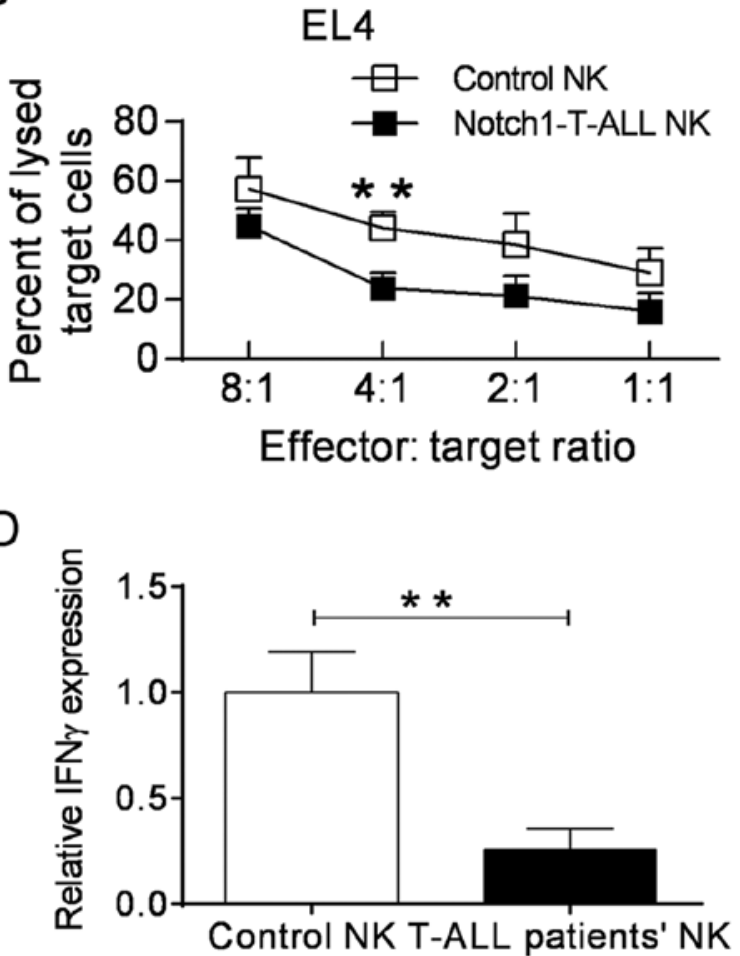

Figure 3. NK cell function is altered in both Notch1-T-ALL mice and patients with T-ALL. Splenic NK1.1 ${ }^{+}$CD3- NK cells were isolated from Notch1-T-ALL mice and control WT C57BL/6 mice. Splenic Notch1-T-ALL blasts were isolated using fluorescence-activated cell sorting from the same Notch1-T-ALL mice. A standard chromium release cytotoxicity assay was performed with autologous (A) Notch1-T-ALL blasts and (B) EL4 murine lymphoma targets at the indicated ratios. (C) Relative IFN $\gamma$ expression levels in splenic NK cells from Notch1-T-ALL mice and control WT C57BL/6 mice. (D) Relative IFN $\gamma$ expression levels in NK cells from the peripheral blood of patients with T-ALL and the healthy control group. (E) Relative NKG2D expression levels of splenic NK cells from Notch1-T-ALL mice and control WT C57BL/6 mice. (F) Relative NKG2D expression levels in NK cells from patients with T-ALL and the healthy control group. A-C and E: $n=10$ mice per group; $D$ and $F: n=8$ healthy control group, $n=8$ untreated patients with T-ALL. The data are presented as the mean \pm standard deviation. ${ }^{*} \mathrm{P}<0.05$ and ${ }^{* *} \mathrm{P}<0.01$, as determined using one-way ANOVA or the unpaired Student's t-test. T-ALL, T-cell acute lymphoblastic leukemia; NK, natural killer; Notch1, neurogenic locus notch homolog protein 1; IFN, interferon; NKG2D, natural killer receptor group 2, member D; ns, not significant.

this may be as a result of T-ALL blasts in the peripheral blood of T-ALL patients. Furthermore, it was observed that the absolute number of CD56 ${ }^{\text {dim }} \mathrm{CD} 16^{\text {bright }} \mathrm{NK}$ cells was decreased in T-ALL patients when compared with that in the healthy control group $\left(8.98 \pm 4.78 \times 10^{7} / 1\right.$ vs. $2.69 \pm 1.34 \times 10^{7} / 1 ; P=0.0245 ;$ Fig. $\left.2 \mathrm{G}\right)$. These data suggested a developmental blockage in CD56 ${ }^{\mathrm{dim}} \mathrm{CD} 16^{\text {bright }}$ NK cell subsets in patients with T-ALL.

Alterations to NK cell function in T-ALL. NK cells serve a critical role in the destruction leukemia blasts. The cytotoxicity of splenic NK cells (from Notch1-T-ALL mice or control WT C57BL/6 mice) towards Notch1-T-ALL blasts or the murine $\mathrm{T}$ cell lymphoma EL4 cell line was assessed by effector-target ratio of the number of cells at $8: 1,4: 1,2: 1,1: 1$, respectively. The cytotoxic capacity of NK cells from Notch1-T-ALL mice was markedly decreased, compared with that of NK cells from WT C57BL/6 mice at an 8:1 (15.17 $\pm 4.12 \%$ vs. $33.73 \pm 6.94 \%$; $\mathrm{P}=0.0163)$ and $4: 1(12.43 \pm 2.42 \%$ vs. $23.20 \pm 3.19 \% ; \mathrm{P}=0.0095)$ ratio, respectively (Fig. 3A). This trend was also observed for EL4 cells, it was statistically significantly at a ratio of 4:1 $(23.80 \pm 5.21 \%$ vs. $44.17 \pm 5.33 \%$; $P=0.0091$; Fig. $3 B)$. To demonstrate whether a reduction in IFN $\gamma$ secretion from NK cells was one of the influencing factors for NK cell cytotoxicity, the relative expression levels of IFN $\gamma$ in NK cells from both 
A

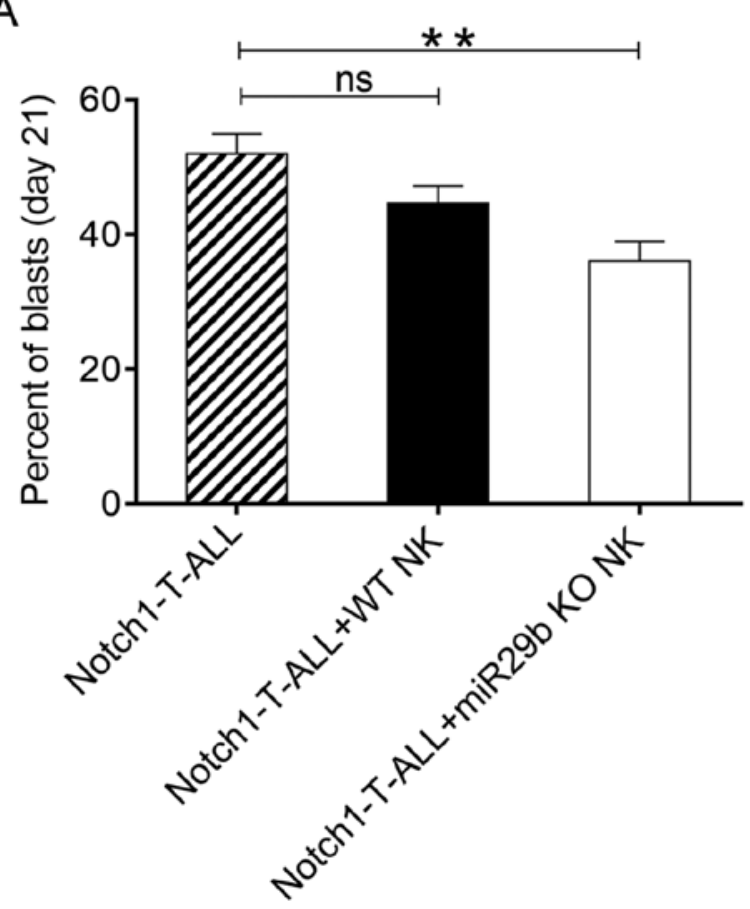

C

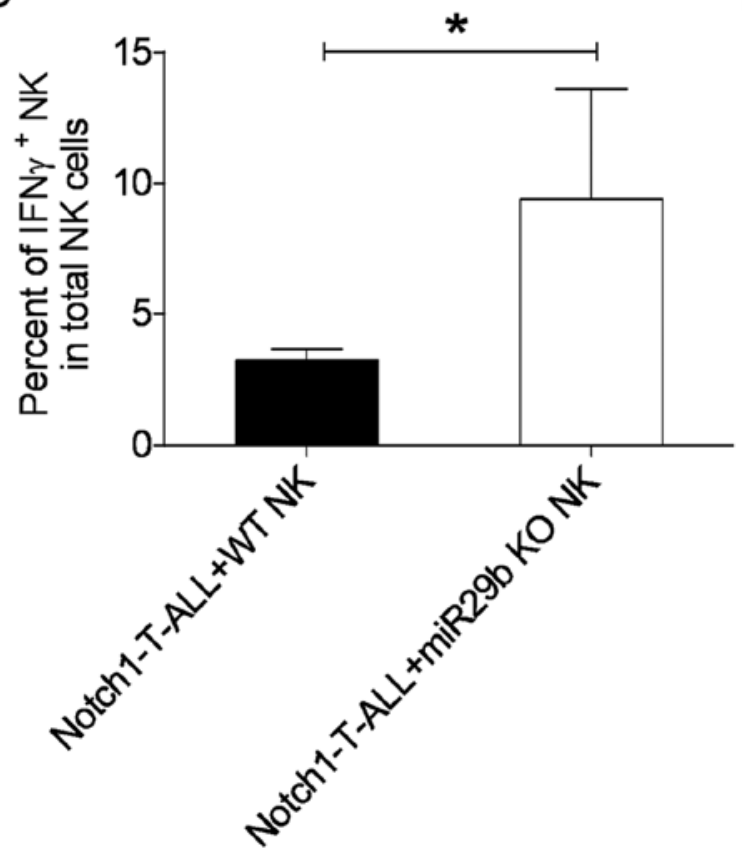

B

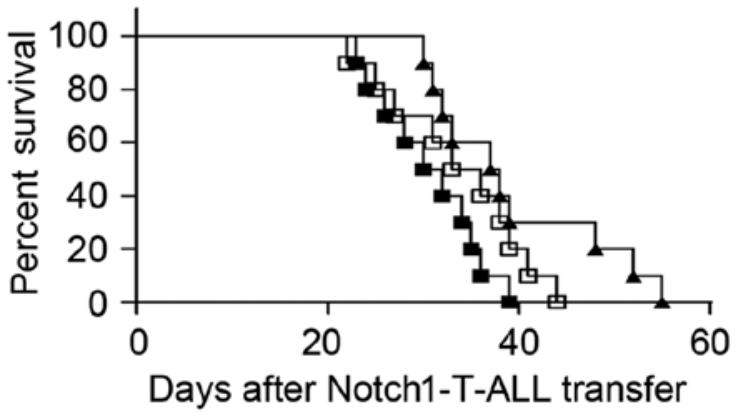

- Notch1-T-ALL

$\square-$ Notch1-T-ALL+WT NK

- Notch1+T-ALL+miR29b KO NK

Figure 4. miR29b KO NK cells decrease ALL progression. Three groups of C57BL/6 Rag2 $2^{-\nsim}$ mice received either $2 \times 10^{5}$ Notch1-T-ALL blasts without

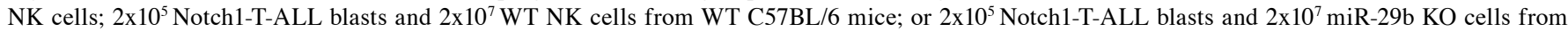
C57BL $/ 6$ miR29ab1 ${ }^{-1}$ mice. (A) Percentages of circulating Notch1-T-ALL blasts were evaluated using flow cytometry. (B) Survival rate was compared between three groups. Notch1-T-ALL, $\mathbf{m}$; Notch1-T-ALL+WT NK cells, $\square$; and Notch1-T-ALL+miR-29b KO NK cells, $\mathbf{\Lambda}$. (C) Percentage of IFN $\gamma^{+}$NK cells in the NK1.1 ${ }^{+}$CD3-NK cell population from Notch1-T-ALL mice transfused with WT NK cells or miR-29b KO NK cells. (D) Relative NKG2D expression levels in NK cells from Notch1-T-ALL mice transfused with WT NK cells or miR-29b KO NK cells. A: $n=10$ mice per group; B: $n=10$ per group (Kaplan-Meier curve and log-rank test); $\mathrm{C}$ and $\mathrm{D}: \mathrm{n}=10$ mice per group. The data are presented as the mean \pm SD. ${ }^{*} \mathrm{P}<0.05$ and ${ }^{* *} \mathrm{P}<0.01$, as determined using one-way ANOVA or the unpaired Student's t-test. miR, microRNA; KO, knock-out; T-ALL, T-cell acute lymphoblastic leukemia; NK, natural killer; WT, wild type; Notch1, neurogenic locus notch homolog protein 1; IFN, interferon; NKG2D, natural killer receptor group 2, member D; ns, not significant.

Notch1-T-ALL mice and WT C57BL/6 mice was evaluated. The results revealed that the relative level of IFN $\gamma$ expression was significantly decreased in NK cells from Notch1-T-ALL mice compared with that of the WT C57BL/6 mice $(0.41 \pm 0.22$ vs. $1.03 \pm 0.27 ; \mathrm{P}=0.0468 ;$ Fig. $3 \mathrm{C})$. Additionally, the expression levels of IFN $\gamma$ in NK cells from patients with T-ALL were significantly decreased when compared with those of the healthy controls $(0.25 \pm 0.22$ vs. $1.02 \pm 0.42 ; \mathrm{P}=0.0086 ;$ Fig. 3D).

The cytotoxic functions of NK cells are regulated by the expression of activating and inhibitory receptors on the cell 
surface. Interactions between the activating receptor NKG2D and its ligands promote IFN $\gamma$ production in NK cells (26). Therefore, alterations to NKG2D expression in NK cells were investigated, which may be associated with the reduction in IFN $\gamma$ production and NK cell cytotoxicity. As predicted, a reduction in the NKG2D expression level was detected in the NK cells of Notch1-T-ALL mice, compared with that of the WT C57BL $/ 6$ mice $(0.7569 \pm 0.31$ vs. $1.03 \pm 0.20 ; \mathrm{P}=0.1036$; Fig. 3E); a similar reduction was observed in T-ALL patients $(0.75 \pm 0.31$ vs. $1.03 \pm 0.29 ; \mathrm{P}=0.1882$; Fig. $3 \mathrm{~F})$. These results suggested that NKG2D expression levels decrease in the leukemia microenvironment of T-ALL, which may be one of factors to influence the reduction of IFN $\gamma$ production.

ALL progression is inhibited in miR-29b KO NK cells. It has previously been demonstrated that miR-29b deletion in NK cells reverses dysregulation in the NK cell subsets and modulates AML progression (17). Subsequently, the impact of miR-29b KO NK cells on the progression of Notch1-T-ALL was assessed. A total of $2 \times 10^{5}$ Notch1-T-ALL blasts were infused into three groups of $\mathrm{C} 57 \mathrm{BL} / 6 \mathrm{Rag} 2^{-/}$recipient mice. In addition, $2 \times 10^{7}$ WT NK cells or miR-29b KO NK cells were adoptively infused into two groups of recipient mice. After 3 weeks, the percentage of circulating Notch1-T-ALL blasts was evaluated. The number of circulating Notch1-T-ALL blasts in mice with WT NK cells was reduced, compared with mice without NK cells $(44.69 \pm 6.81 \%$ vs. $52.03 \pm 7.85 \%$; $\mathrm{P}=0.0885$; Fig. 4A). Notably, the number of Notch1-T-ALL blasts decreased significantly in mice with miR-29b KO NK cells, compared with those without $(36.09 \pm 7.60 \%$ vs. $52.03 \pm 7.85 \%$; $\mathrm{P}=0.0023$; Fig. 4A). Also, improved survival time was observed in mice with WT NK cells compared with those without NK cells. Specifically, a significant improvement was observed in mice receiving miR-29b KO NK cells $(\mathrm{P}=0.0230)$, compared with mice without NK cell infusion. These results suggested that miR-29b KO NK cells served a crucial role in controlling the progression of T-ALL.

Following the deletion of miR-29b in Notch1-T-ALL mice, NK cell function was restored and survival time subsequently improved. The percentage of IFN $\gamma^{+} \mathrm{NK}$ cells and relative NKG2D expression levels in the NK1.1 ${ }^{+} \mathrm{CD} 3-\mathrm{NK}$ cell population was determined. The results demonstrated that both of these factors were significantly increased in Notch1-T-ALL mice infused with miR-29b KO NK cells, compared with those infused with WT NK cells $[(9.39 \pm 4.22$ vs. $3.23 \pm 1.38$; $\mathrm{P}=0.0143$; Fig. $4 \mathrm{C})$ and $(1.02 \pm 0.44$ vs. $0.55 \pm 0.32$; $\mathrm{P}=0.0282$; Fig. 4D) respectively]. Therefore, the mechanism of miR-29b KO NK cells in regulating T-ALL progression may involve IFN $\gamma$ production and/or NKG2D expression in the NK cells of Notch1-T-ALL mice.

\section{Discussion}

NK cell-based immunotherapeutic strategies have shown great promise in patients with AML and consist in infusions of alloreactive NK cells with KIR ligand mismatch that protect against AML relapse (4). Similar types of treatments have been less successful for patients with ALL, which may be due to the increased resistance of T-ALL blasts to NK cell cytotoxicity, as they less frequently express ligands for activating NK cell receptors $(6,27)$. Additionally, the available research on T-ALL blast resistance to NK cells is fragmentary. The present study revealed an increase in the miR-29b expression levels of NK cells, with a reduction in miR-29b expression in T-ALL blasts. Furthermore, the NK phenotype was determined, which revealed a selective downregulation of $\mathrm{CD} 27^{+} \mathrm{CD} 11 \mathrm{~b}^{+} \mathrm{NK}$ cell subset. In addition, NK cell alterations included a reduction in IFN $\gamma$ production, decreased NKG2D expression levels and impaired cytotoxicity in T-ALL, which was associated with increased miR-29b expression levels in NK cells.

miR-29 family members have been shown to be downregulated in AML, as well as in chronic lymphocytic leukemia (23). Furthermore, a reduced expression level of miR-29b in AML blasts has been shown to correlate with disease progression $(23,24)$. As a result, the overexpression of miR-29b enhanced the apoptosis of AML blasts. Previous studies have identified that miR-29b interferes with the development of $\mathrm{CD}^{+} \mathrm{T}$ cells by regulating T-box-related TBX21 (T-bet) and eomesodermin (Eomes) expression $(28,29)$. Furthermore, in NK cells from T-bet or Eomes KO mice, the resulting inhibition of terminal differentiation was associated with a lack of CD11 $\mathrm{b}^{+} \mathrm{NK}$ cells (30). In the AML microenvironment, increased miR-29b expression in NK cells altered NK differentiation by regulating T-bet and Eomes (17). However, to the best of our knowledge, miR-29b expression in NK cells was yet to be evaluated in the T-ALL microenvironment.

In the present study, miR-29b expression in NK cells was initially determined in both Notch1-T-ALL mice and T-ALL patients. The results revealed that in Notch1-T-ALL mice (Fig. 1A) and T-ALL patients (Fig. 1B), miR-29b expression of NK cells was upregulated, but miR-29b expression of T-ALL blasts (Fig. 1C and D) was downregulated. Previous studies have reported that elevated levels of miR-29b in NK cells may be associated with the exchange of miR-29b released from chronic leukemia blasts $(25,31)$. Exosomes and vesicles are involved in the transfer of miR-29b between cells, as well as leukemia progression and immune suppression $(25,32)$. Further studies that focus on the mechanisms of miR-29b expression regulation are required.

A blockage in NK cell differentiation was also observed in both Notch1-T-ALL mice and patients with T-ALL. In the mouse model, the percentage and absolute number of $\mathrm{CD} 27^{+} \mathrm{CD} 11 \mathrm{~b}^{+}$ NK cells decreased in mice with leukemia, compared with the control group. Comparatively, a decreased percentage and absolute number of $\mathrm{CD} 56^{\text {bright }} \mathrm{CD} 16^{\mathrm{dim}} \mathrm{NK}$ cells was also observed in patients with T-ALL, compared with the healthy control group. This result was consistent with a previous study which reported that NK cell development is arrested in AML (17); this study demonstrated that the increased level of miR-29b expression in NK cells downregulated T-bet and Eomes in AML mice, which resulted in the accumulation of $\mathrm{CD}_{2} 7^{+} \mathrm{CD} 11 \mathrm{~b}-\mathrm{NK}$ cells and a reduction in $\mathrm{CD} 27^{+} \mathrm{CD} 11 \mathrm{~b}^{+} \mathrm{NK}$ cells.

Furthermore, a decrease in the percentage and absolute number of the CD56 $6^{\text {bright }} \mathrm{CD} 16^{\mathrm{dim}} \mathrm{NK}$ cell subset was demonstrated in untreated T-ALL patients, compared with the control group. This suggested that T-ALL blasts selectively eliminate this NK subset and block NK cell maturation, which results in NK cell immune surveillance failure. A previous report indicated that the absolute number of CD56 $6^{\text {bright }} \mathrm{NK}$ cells increased at the complete remission stage of leukemia (33). 
Furthermore, Mundy-Bosse et al (17) demonstrated that the depletion of miR-29b restored the intermediate $\mathrm{CD} 27^{+} \mathrm{CD} 11 \mathrm{~b}^{+}$ NK cell population in AML. In the present study, although the impact of adoptively transferred miR-29b KO NK cells on the restoration of NK cells subsets was not investigated, the impact of these cells on NK cell function in the Notch1-T-ALL microenvironment was determined.

In the present study, NK cell cytotoxicity towards Notch1-T-ALL cells and EL4 murine lymphoma cells was significantly decreased in Notch1-T-ALL mice, compared with WT C57BL/6 mice. NK cells secrete cytokines that kill target cells and influence the host immune response $(13,34)$. As a prototypical NK cell cytokine, IFN $\gamma$ activates antigen-presenting cells to induce MHC-I expression (35), and inhibits the proliferation of malignant cells (36). As the primary producer of IFN $\gamma$, two signals are involved in IFN $\gamma$ production by CD56 $6^{\text {bright }} \mathrm{NK}$ cells; NKG2D, a critical NK-activating receptor expressed on all cells from the NK cell lineage (37), is involved in IFN $\gamma$ production and NK cell activation $(11,38)$, and is also fundamentally involved in the NK cell-mediated antitumor and antiviral immune responses $(15,39)$. The upregulation of NKG2D promotes IFN $\gamma$ secretion via co-stimulatory signaling of NK cells (40). When NKG2D is blocked, fewer NK cells secrete IFN $\gamma$ (41). In the present study, relative NKG2D expression on NK cells was significantly decreased in both Notch1-T-ALL mice and patients with T-ALL, implying that the cytotoxicity of NK cells was decreased in the lymphoblastic leukemia microenvironment. Accordingly, IFN $\gamma$ secretion by NK cells significantly decreased in both Notch1-T-ALL mice and patients with T-ALL. The reduction in IFN $\gamma$ secretion was in line with a previous study, which reported that the reduction in intracellular IFN $\gamma$ production by NK cells was associated with an elevation in miR-29b expression in the AML microenvironment (17). It was further hypothesized that the increase in miR-29b expression level in the present study may have been associated with a reduction in IFN $\gamma$ production. When Notch1-T-ALL mice received miR-29b KO NK cells, the partial restoration of NK cell IFN $\gamma$ production and NKG2D expression were observed. Furthermore, adoptive transfusion of miR-29b KO NK cells into Notch1-T-ALL mice promoted ALL progression and improved survival time. These results identified the elevation of miR-29b expression level as one of the contributing factors to decreased NK cell function in the T-ALL microenvironment. Further research is required to determine how miR-29b affects NK cell IFN $\gamma$ production and NKG2D expression in T-ALL.

To conclude, the present study identified previously unknown NK cell defects that are associated with miR-29b dysregulation in the T-ALL microenvironment. Alterations in NK cell maturation and function resulted in decreased NK cytotoxicity in T-ALL, suggesting that miR-29b is involved in NK cell development arrest and functional defects, which is used by leukemia cells to evade immune surveillance in T-ALL. Further research is required to reveal the mechanism driving this phenomenon, and solutions that restore NK cell maturation and function to decrease T-ALL relapse.

\section{Acknowledgements}

The authors would like to thank Dr Mengmeng Liu and Dr Fuming Zhang for their technical support.

\section{Funding}

The present study was supported by the Norman Bethune Program of Jilin University (grant no. 2012224) and the National Natural Science Foundation of China (grant nos. 81770149 and 81100350).

\section{Availability of data and materials}

The datasets used and/or analyzed during the present study are available from the corresponding author on reasonable request.

\section{Author's contributions}

YPY designed the study, provided funding and was a major contributor in writing the manuscript. FYJ, ZHD, YT and LXW performed the examinations. FYJ analyzed and interpreted the patient data, and ZHD curated the data. All authors read and approved the final manuscript.

\section{Ethics approval and consent to participate}

Each patient provided written informed consent and the study was approved by the Ethical Review Board of the First Bethune Hospital of Jilin University (protocol no. 2017-004). The research was performed according to the Guidance on the Operation of the Animals (Scientific Procedures) Act 1986, as well as the Care and Use of Laboratory Animals of the National Institutes of Health.

\section{Patient consent for publication}

Patients consented to publication of the article.

\section{Competing interests}

The authors declare that they have no competing interests.

\section{References}

1. Onciu M: Acute lymphoblastic leukemia. Hematol Oncol Clin North Am 23: 655-674, 2009.

2. Rouce RH, Shaim H, Sekine T, Weber G, Ballard B, Ku S, Barese C, Murali V, Wu MF, Liu H, et al: The TGF- $\beta /$ SMAD pathway is an important mechanism for NK cell immune evasion in childhood B-acute lymphoblastic leukemia. Leukemia 30: 800-811, 2016.

3. Oelsner S, Wagner J, Friede ME, Pfirrmann V, Genßler S, Rettinger E, Buchholz CJ, Pfeifer H, Schubert R, Ottmann OG, et al: Chimeric antigen receptor-engineered cytokine-induced killer cells overcome treatment resistance of pre-B-cell acute lymphoblastic leukemia and enhance survival. Int J Cancer 139: 1799-1809, 2016.

4. Miller JS, Soignier Y, Panoskaltsis-Mortari A, McNearney SA, Yun GH, Fautsch SK, McKenna D, Le C, Defor TE, Burns LJ, et al: Successful adoptive transfer and in vivo expansion of human haploidentical NK cells in patients with cancer. Blood 105: 3051-3057, 2005.

5. Pende D, Spaggiari GM, Marcenaro S, Martini S, Rivera P, Capobianco A, Falco M, Lanino E, Pierri I, Zambello R, et al: Analysis of the receptor-ligand interactions in the natural killer-mediated lysis of freshly isolated myeloid or lymphoblastic leukemias: Evidence for the involvement of the Poliovirus receptor (CD155) and Nectin-2 (CD112). Blood 105: 2066-2073, 2005.

6. Romanski A, Bug G, Becker S, Kampfmann M, Seifried E, Hoelzer D, Ottmann OG and Tonn T: Mechanisms of resistance to natural killer cell-mediated cytotoxicity in acute lymphoblastic leukemia. Exp Hematol 33: 344-352, 2005. 
7. Sanchez-Correa B, Morgado S, Gayoso I, Bergua JM, Casado JG Arcos MJ, Bengochea ML, Duran E, Solana R and Tarazona R: Human NK cells in acute myeloid leukaemia patients: Analysis of NK cell-activating cellactivating receptors and their ligands. Cancer Immunol Immunother 60: 1195-1205, 2011.

8. Lion E, Willemen Y, Berneman ZN, Van Tendeloo VF and Smits EL: Natural killer cell immune escape in acute myeloid leukemia. Leukemia 26: 2019-2026, 2012.

9. Chiossone L, Chaix J, Fuseri N, Roth C, Vivier E and Walzer T: Maturation of mouse NK cells is a 4-stage developmental program. Blood 113: 5488-5496, 2009.

10. Hayakawa Y and Smyth MJ: CD27 dissects mature NK cells into two subsets with distinct responsiveness and migratory capacity. J Immunol 176: 1517-1524, 2006.

11. Cooper MA, Fehniger TA, Turner SC, Chen KS, Ghaheri BA, Ghayur T, Carson WE and Caligiuri MA: Human natural killer cells: A unique innate immunoregulatory role for the CD56 (bright) subset. Blood 97: 3146-3151, 2001.

12. Yu J, Freud AG and Caligiuri MA: Location and cellular stages of natural killer cell development. Trends Immunol 34: 573-582, 2013.

13. Caligiuri MA: Human natural killer cells. Blood 112: 461-469, 2008.

14. Chan A, Hong DL, Atzberger A, Kollnberger S, Filer AD, Buckley CD, McMichael A, Enver $T$ and Bowness $P$ CD56bright human NK cells differentiate into CD56dim cells: Role of contact with peripheral fibroblasts. J Immunol 179: 89-94, 2007.

15. Jin F, Lin H, Gao S, Hu Z, Zuo S, Sun L, Jin C, Li W and Yang Y The anti-tumor role of NK cells in vivo pre-activated and re-stimulated by interleukins in acute lymphoblastic leukemia. Oncotarget 7: 79187-79202. 2016.

16. Wu J, Song Y, Bakker AB, Bauer S, Spies T, Lanier LL and Phillips JH: An activating immunoreceptor complex formed by NKG2D and DAP10. Science 285: 730-732, 1999.

17. Mundy-Bosse BL, Scoville SD, Chen L, McConnell K, Mao HC, Ahmed EH, Zorko N, Harvey S, Cole J, Zhang X, et al: MicroRNA-29b mediates altered innate immune development in acute leukemia. J Clin Invest 126: 4404-4416, 2016.

18. Leong JW, Sullivan RP and Fehniger TA: MicroRNA management of NK-cell developmental and functional programs. Eur J Immunol 44: 2862-2868, 2014.

19. Weng AP, Ferrando AA, Lee W, Morris JP IV, Silverman LB, Sanchez-Irizarry C, Blacklow SC, Look AT and Aster JC: Activating mutations of NOTCH1 in human T cell acute lymphoblastic leukemia. Science 306: 269-271, 2004.

20. Kloss M, Decker P, Baltz KM,Baessler T, Jung G, Rammensee HG Steinle A, Krusch M and Salih HR: Interaction of monocytes with NK cells upon Toll-like receptor-induced expression of the NKG2D ligand MICA. J Immunol 181: 6711-6719, 2008.

21. Yang Y, Wang H, Yu H, Yeap BY, Liang T, Wang G, Cheng T and Yang YG: IFN- $\gamma$ promotes graft-versus-leukemia effects without directly interacting with leukemia cells in mice after allogeneic hematopoietic cell transplantation. Blood 118 3721-3724, 2011

22. Lieberman NAP, DeGolier K, Haberthur K, Chinn $H$, Moyes KW, Bouchlaka MN, Walker KL, Capitini CM and Crane CA: An uncoupling of canonical phenotypic markers and functional potency of ex vivo-expanded natural killer cells. Front Immunol 9: 150, 2018.

23. Garzon R, Heaphy CE, Havelange V, Fabbri M, Volinia S, Tsao T, Zanesi N, Kornblau SM, Marcucci G, Calin GA, et al: MicroRNA 29b functions in acute myeloid leukemia. Blood 114 5331-5341, 2009

24. Liu S, Wu LC, Pang J, Santhanam R, Schwind S, Wu YZ, Hickey CJ, Yu J,BeckerH,Maharry K, et al: Sp1/NFkappaB/HDAC/miR-29b regulatory network in KIT-driven myeloid leukemia. Cancer Cell 17: 333-347, 2010.

25. Huan J, Hornick NI, Shurtleff MJ, Skinner AM, Goloviznina NA Roberts CT Jr and Kurre P: RNA trafficking by acute myelogenous leukemia exosomes. Cancer Res 73: 918-929, 2013.
26. Boukouaci W, Al-Daccak R, Dulphy N, Lauden L, Amokrane K, Fortier C, Marzais F, Bennabi M, Peffault de Latour R, Socie G, et al: Soluble MICA-NKG2D interaction upregulates IFN- $\gamma$ production by activated CD3-CD56+ NK cells: Potential impact on chronic graft versus host disease. Hum Immunol 74: 1536-1541, 2013.

27. Boieri M, Ulvmoen A, Sudworth A, Lendrem C, Collin M, Dickinson AM, Kveberg L and Inngjerdingen M: IL-12, IL-15, and IL-18 pre-activated NK cells target resistant T cell acute lymphoblastic leukemia and delay leukemia development in vivo. Oncoimmunology 6: e1274478, 2017.

28. Steiner DF, Thomas MF, Hu JK, Yang Z, Babiarz JE, Allen CD, Matloubian M, Blelloch R and Ansel KM: MicroRNA-29 regulates T-box transcription factors and interferon- $\gamma$ production in helper T cells. Immunity 35: 169-181, 2011

29. Smith KM, Guerau-de-Arellano M, Costinean S, Williams JL, Bottoni A, Mavrikis Cox G, Satoskar AR, Croce CM, Racke MK, Lovett-Racke AE and Whitacre CC: miR-29ab1 deficiency identifies a negative feedback loop controlling Th1 bias that is dysregulated in multiple sclerosis. J Immunol 189: 1567-1576, 2012.

30. Gordon SM, Chaix J, Rupp LJ, Wu J, Madera S, Sun JC, Lindsten T and Reiner SL: The transcription factors T-bet and Eomes control key checkpoints of natural killer cell maturation. Immunity 36: 55-67, 2012.

31. Yeh YY, Ozer HG, Lehman AM, Maddocks K, Yu L, Johnson AJ and Byrd JC: Characterization of CLL exosomes reveals a distinct microRNA signature and enhanced secretion by activation of BCR signaling. Blood 125: 3297-3305, 2015.

32. Whiteside TL: Immune modulation of T-cell and NK (natural killer) cell activities by TEXs (tumour-derived exosomes). Biochem Soc Trans 41: 245-251, 2013.

33. Dauguet N, Récher C, Demur C, Fournié JJ, Poupot M and Poupot R: Pre-eminence and persistence of immature natural killer cells in acute myeloid leukemia patients in first complete remission. Am J Hematol 86: 209-213, 2011.

34. Smyth MJ, Cretney E, Kelly JM, Westwood JA, Street SE, Yagita H, Takeda K, van Dommelen SL, Degli-Esposti MA and Hayakawa Y: Activation of NK cell cytotoxicity. Mol Immunol 42: 501-510, 2005.

35. Wallach D, Fellous M and Revel M: Preferential effect of gamma interferon on the synthesis of HLA antigens and their mRNAs in human cells. Nature 299: 833-836, 1982.

36. Maher SG, Romero-Weaver AL, Scarzello AJ and Gamero AM Interferon: Cellular executioner or white knight? Curr Med Chem 14: 1279-1289, 2007

37. Jelenčić V, Lenartić M, Wensveen FM and Polić B: NKG2D: A versatile player in the immune system. Immunol Lett 189: 48-53, 2017.

38. Moretta A, Bottino C, Vitale M,Pende D, Cantoni C, Mingari MC, Biassoni R and Moretta L: Activating receptors and coreceptors involved in human natural killer cell-mediated cytolysis. Annu Rev Immunol 19: 197-223, 2001.

39. Mistry AR and $\mathrm{O}^{\prime}$ Callaghan CA: Regulation of ligands for the activating receptor NKG2D. Immunology 121: 439-447, 2007.

40. Girart MV, Fuertes MB, Domaica CI, Rossi LE and Zwirner NW: Engagement of TLR3, TLR7, and NKG2D regulate IFN-gamma secretion but not NKG2D-mediated cytotoxicity by human NK cells stimulated with suboptimal doses of IL-12. J Immunol 179: 3472-3479, 2007.

41. Kim JY, Huh K, Lee KY, Yang JM and Kim TJ: Nickel induces secretion of IFN-gamma by splenic natural killer cells. Exp Mol Med 41: 288-295, 2009.

This work is licensed under a Creative Commons Attribution-NonCommercial-NoDerivatives 4.0 International (CC BY-NC-ND 4.0) License. 